\title{
宮崎医大および県立宮崎病院における 気道・食道異物の臨床統計的観察
}

$\begin{aligned} * \text { 狩野 } & \text { 季代, 安達裕一郎, 井手 稔 } \\ \text { 永井 } & \text { 知幸, 森満 保 } \\ * * \text { 東野 } & \text { 哲也, 松元 一郎 }\end{aligned}$

\section{Statistical Analysis of Tracheo-bronchial and Esophageal Foreign Bodies}

\author{
Kiyo Kano, M.D., Yuichiro Adachi, M.D., Minoru Ide, M.D., \\ Tomoyuki Nagai, M.D. and Tamotsu Morimitsu, M.D. \\ Department of Otorhinolaryngology, Miyazaki Medical College, Miyazaki \\ Tetsuya Tono, M.D. and Ichiro Matsumoto, M.D. \\ Department of Otorhinolaryngology, Miyazaki Prefectural Hospital, Miyazaki
}

1. One hundred and three cases of tracheo-bronchial and esophageal foreign bodies treated in Miyazaki Medical College and Miyazaki Prefectural Hospital during the past nine years were statistically analyzed and reported.

2. In regard to the esophageal foreign bodies, coins ranked first and followed by fish bones and pieces of meat. Sixty percent of foreign bodies were radiolucent.

3. In regard to the tracheo-bronchial foreign bodies, beans were found in seventy percent of cases. Unexpectedly, the foreign bodies were lodged in the left bronchus 2.5 times more frequently than in the right bronchus.

4. Effectiveness of capsule esophagography and pulmonary scintigraphy was evaluated in cases of radiolucent foreign bodies.

Key words : 食道異物, 気道異物, 気道・食道異物統計

\section{1. 緒言}

耳鼻咽喉科領域における異物症のなかで気道

・食道異物は救急救命的要素を備えており，ま た小児患者が多いため，総合病院に集められる 傾向にある。今回, 当教室開講以来約 9 年間を 経過したので, 気道・食道異物症例について臨 床統計的観察を行い，功同期間内における県 立宮崎病院（以下県病院）の症例と比較検討し たので報告する。

$*$ 宮崎医科大学耳鼻咽喉科学教室

**宮崎県立宮崎病院耳鼻咽喉科

\section{2. 集 計 結 果}

対象は昭和 53 年 1 月から 61 年 8 月までに宮崎 医大および県病院耳鼻咽喉科において入院加療 を行い, 異物を摘出し得た症例である。

1 . 食道異物

1) 症例数と男女比（表 1)

当大学は宮崎市より離れた場所に立地し，救 急外来を開設していないため症例数は少なく, 13例で男女比は $12 ： 1$ であった。一方, 県病院は 市街地にある総合病院で, 症例数は65例と 5 倍 多く，男女比は $9: 7$ と女性の割合が多かった。 
表 1 年度別症例数

\begin{tabular}{|c|c|c|c|c|c|c|c|c|c|c|c|c|}
\hline \multirow{3}{*}{ 年 度 } & \multicolumn{6}{|c|}{ 宮崎医 科大学 } & \multicolumn{6}{|c|}{ 県 立 宮 崎 病 院 } \\
\hline & \multicolumn{3}{|c|}{ 食道異物 } & \multicolumn{3}{|c|}{ 気道異物 } & \multicolumn{3}{|c|}{ 食道異物 } & \multicolumn{3}{|c|}{ 気 道 異物 } \\
\hline & 男 & 女 & 計 & 男 & 女 & 計 & 男 & 女 & 計 & 男 & 女 & 計 \\
\hline 53 & & & & & & & 4 & 3 & 7 & 0 & 2 & 2 \\
\hline 54 & & & & 1 & & 1 & 3 & 2 & 5 & 4 & & 4 \\
\hline 55 & 2 & & 2 & & & & 2 & 3 & 5 & 1 & 1 & 2 \\
\hline 56 & 3 & & 3 & & 1 & 1 & 6 & 2 & 8 & 2 & & 2 \\
\hline 57 & 2 & & 2 & & & & 7 & 2 & 9 & & 2 & 2 \\
\hline 58 & 2 & 1 & 3 & & & & 6 & 6 & 12 & 2 & 1 & 3 \\
\hline 59 & 2 & & 2 & & & & 5 & 2 & 7 & 3 & & 3 \\
\hline 60 & & & & 3 & & 3 & 1 & 3 & 4 & 1 & & 1 \\
\hline 61 & 1 & & 1 & & & & 3 & 5 & 8 & 1 & & 1 \\
\hline 計 & 12 & 1 & 13 & 4 & 1 & 5 & 37 & 28 & 65 & 14 & 6 & 20 \\
\hline
\end{tabular}

表 2 食道異物の種類と年齢分布（宮崎医科大学）

\begin{tabular}{c|c|c|c|c|c|c|c}
\hline & 魚 骨 & 貨 幣 & 肉 片 & 押ピン & 義 歯 & 玩 具 & 計 \\
\hline $0 \sim 2$ & & 2 & & 2 & & 1 & 5 \\
$3 \sim 5$ & & 1 & & & & & 1 \\
$6 \sim 9$ & & & 1 & & & & 1 \\
$10 \sim 19$ & & & & & & & 0 \\
$20 \sim 29$ & 1 & & 1 & & & & 1 \\
$30 \sim 39$ & & & & & & & 0 \\
$40 \sim 49$ & 1 & & & & & & 1 \\
$50 \sim 59$ & 1 & & & & & & \\
$60 \sim 69$ & & & & & & & 1 \\
$70 \sim$ & & & & & & & 1 \\
\hline 計 & 3 & & & & & & 1 \\
\hline
\end{tabular}

表 3 食道異物の種類と年齢分布（県立宮崎病院）

\begin{tabular}{c|c|c|c|c|c|c|c|c|c|c}
\hline & 貨 幣 & 魚 骨 & 鵎 骨 & P T P & 肉 片 & 梅干し & 義 歯 & 碁 石 & その他 & 計 \\
\hline $0 \sim 2$ & 12 & & & & & & & & & 13 \\
$3 \sim 5$ & 4 & & & & & & & 1 & & 5 \\
$6 \sim 9$ & 2 & & & & & & & & 2 & 4 \\
$10 \sim 19$ & 1 & & & & 1 & & & & 1 & 3 \\
$20 \sim 29$ & & & 1 & & & & & & 1 & 2 \\
$30 \sim 39$ & & 1 & 2 & & & & 1 & & & 4 \\
$40 \sim 49$ & & 2 & 1 & 2 & 1 & & 1 & & & 7 \\
$50 \sim 59$ & & 4 & 1 & & 2 & & & & & 7 \\
$60 \sim 69$ & & 3 & 2 & 1 & 1 & 1 & & & & 8 \\
$70 \sim$ & & 5 & & 3 & & 3 & 1 & & & 12 \\
\hline 計 & 19 & 15 & 7 & 6 & 5 & 4 & 3 & 2 & 4 & 65 \\
\hline
\end{tabular}


2 ）異物の種類と年齢分布（表 $2 ， 3$ ）

当科では貨幣・魚骨・肉片で 7 割を占め, 年 齢的には貨幣・プラスチック玩具が小児に, 肉 片・魚骨・義歯が成人に多くみられた。県病院 も貨幣・魚骨の順に多かったが, 欧米では 1 位 を占める鶏骨が 3 位であった。貨幣・碁石が小 児に，魚骨・鵎骨・PTPが成人に多かった。そ の他は押ピン ( 6 歳), プラスチック玩具 ( 8 歳), つり針 (12歳)，まんじゅうの敷皮 (25歳) であ った。

3 ）異物の種類と介在部位（表 4, 5 ）

両病院とも第 1 狭窄部が最も多く, $55 \%$ を占 め, 第 2 , 第 3 狭窄部の順であった。貨幣は第 1 狭窄部を過ぎると落下しやすいと言われる が，第 2 , 第 3 狭窄部にもみられた。PTP は 6 例中 5 例が第 1 狭窄部であった。

4) 摘出までの日数 (表 6 )

両病院とも当日, 翌日摘出が多く, 大差なか ったが，当科で 40 日目摘出などの長期例がみら れた。

5 ) 摘出方法

当科13例中 8 例 (62\%), 県病院65例中 55 例 (84 \%) が全麻下硬性鏡, 残りは局麻下硬性鏡にて の摘出であった。幸い外切開を要した症例はな く, 摘出後の合併症はなかった。

2. 気道異物

1) 症例数と男女比（表 1 )

症例数は食道異物の約 $1 / 3$ の 25 症例となって おり, 男女比は当科 $4: 1$, 県病院 $7: 3$ といずれ も男性に多かった。

\section{2) 異物の種類と年齢 (表 7,8)}

当科ではピーナッツが 5 例中 1 例であった が, 県病院では20例中15例を占め, 圧倒的に多 数であった。歯冠, PTP が70歳以上の高齢者で, 他は 6 歳以下の子供であり, 特に 3 歳未満が 65 \%を占めた。

3 ) 異物の種類と介在部位（表 9)

両病院を総合すると, 気管内 3 例, 左気管支 15 例, 右気管支 6 例, 両側 1 例という結果であ った。PTPは 2 例とも高齢者で気管内であり, 小児ではピーナッツが多く左気管支に多かっ た。

4 ）摘出までの日数 (表 6 )

当科では院内歯科治療中誤嚥した歯冠異物を
表 4 食道異物の種類と介在部位 (宮崎医科大学)

\begin{tabular}{c|c|c|c|c}
\hline & 第1狭窄部 & 第2狭窄部 & 第3狭窄部 & 不 明 \\
\hline 貨 幣 & 2 & 1 & & \\
魚 骨 & & 3 & & \\
肉 片 & 1 & 1 & & 1 \\
押ピン & 2 & & & \\
義 歯 & 1 & & & \\
玩 具 & 1 & & & \\
\hline 計 & 7 & 5 & 0 & 1 \\
\hline
\end{tabular}

表 5 食道異物の種類と介在部位（県立宮崎病院）

\begin{tabular}{|c|c|c|c|c|}
\hline & 第1狭窄部 & 第2狭窄部 & 第3狭窄部 & 不明 \\
\hline 貨 幣 & 11 & 5 & 2 & 1 \\
\hline 骨 & 7 & 6 & 2 & \\
\hline 骨 & 3 & 2 & 1 & 1 \\
\hline $\mathrm{P} T \mathrm{P}$ & 5 & 1 & & \\
\hline 肉片 & 1 & 2 & 2 & \\
\hline 梅干の種 & 1 & 2 & 1 & \\
\hline 義 歯 & 2 & 1 & & \\
\hline 碁 石 & 2 & & & \\
\hline その他 & 3 & 1 & & \\
\hline 計 & 35 & 20 & 8 & 2 \\
\hline
\end{tabular}

表 6 摘出までの日数

\begin{tabular}{c|c|c|c|c}
\hline \multirow{2}{*}{} & \multicolumn{2}{|c|}{ 宮崎医科大学 } & \multicolumn{2}{c}{ 県立宮崎病院 } \\
\cline { 2 - 5 } & 食道異物 & 気道異物 & 食道異物 & 気道異物 \\
\hline 当日 & 9 & 1 & 28 & 5 \\
翌日 & 2 & & 21 & 11 \\
2 日目 & & & 4 & 1 \\
3 日目 & 1 & & 3 & 1 \\
$4 \sim 7 日$ 日 & & & 4 & 1 \\
$8 \sim 14$ 日目 & & 1 & 5 & \\
15 28日目 & & 2 & & 1 \\
29日目以降 & 1 & 1 & & \\
\hline
\end{tabular}

除き，他は長期介在例が多かった。

5 ) 摘出方法

県病院の声門直下の PTP 異物 1 例を局麻下 に摘出した以外は, 全例全麻下に ventilation bronchoscope を用いて摘出した。気管切開を 要した症例，すなわち下気管支鏡によるものは なかった。 
表 7 気道異物症例（宮崎医科大学）

\begin{tabular}{c|c|l|l|l|l|c}
\hline & 年 齢 & 性 別 & 異物の種類 & 介在部位 & 摘出日 & 麻 酔 \\
\hline 1 & 5 & 男 & アーモンド & 左気管支 & 10 日目 & 全 \\
2 & 79 & 女 & 歯冠 & 左気管支 & 当 日 & 全 \\
3 & 3 & 男 & ピーナッツ & 左気管支 & 35 日目 & 全 \\
4 & 1 & 男 & 䳕骨 & 左気管支 & 17日目 & 全 \\
5 & 6 & 男 & 玩具 & 左気管支 & 23 日目 & 全 \\
& & & (鉄砲の弾) & & & \\
\hline
\end{tabular}

表 8 気道異物症例（県立宮崎病院）

\begin{tabular}{r|c|c|c|c|c|c}
\hline & 年 齢 & 性 別 & 異物の種類 & 介在部位 & 摘出日 & 麻 酔 \\
\hline 1 & 0 & 女 & 玩具(キャップ) & 右気管支 & 翌日 & 全 \\
2 & 0 & 女 & ピーナッツ & 右気管支 & 翌日 & 全 \\
3 & 0 & 男 & ピーナッツ & 左気管支 & 翌日 & 全 \\
4 & 77 & 男 & PTP & 気管 & 翌日 & 全 \\
5 & 1 & 男 & とうもろこし & 左気管支 & 翌日 & 全 \\
6 & 2 & 男 & ピーナッツ & 左気管支 & 日目 & 全 \\
7 & 3 & 男 & ピーナッツ & 左気管支 & 翌日 & 全 \\
8 & 1 & 女 & ピーナッツ & 右気管支 & 当日 & 全 \\
9 & 1 & 男 & ピーナッツ & 左気管支 & 3 日目 & 全 \\
10 & 4 & 男 & ピーナッツ & 右気管支 & 翌日 & 全 \\
11 & 0 & 女 & ピーナッツ & 気管 & 当日 & 全 \\
12 & 1 & 女 & ピーナッツ & 左気管支 & 翌日 & 全 \\
13 & 1 & 男 & アーモンド & 左気管支 & 翌日 & 全 \\
14 & 1 & 男 & ピーナッツ & 左気管支 & 当日 & 全 \\
15 & 1 & 女 & ピーナッツ & 左気管支 & 当日 & 全 \\
16 & 72 & 男 & PTP & 気管 & 4 日目 & 局 \\
17 & 1 & 男 & ピーナッツ & 右気管支 & 翌日 & 全 \\
18 & 1 & 男 & ピーナッツ & 両気管支 & 当日 & 全 \\
19 & 1 & 男 & ピーナッツ & 左気管支 & 16日目 & 全 \\
20 & 1 & 男 & ピーナッツ & 右気管支 & 翌日 & 全 \\
\hline
\end{tabular}

表 9 気道異物の種類と介在部位

\begin{tabular}{|c|c|c|c|c|c|}
\hline & 気 管 & 右気管支 & 左気管支 & 両気管支 & 計 \\
\hline $\begin{array}{c}\text { ピーナッツ } \\
\text { アーモンド } \\
\text { PT T P } \\
\text { 鵎 骨 } \\
\text { 歯 冠 } \\
\text { とうもろこし } \\
\text { キャップ } \\
\text { 鉄砲の弾 }\end{array}$ & $\begin{array}{l}1 \\
2\end{array}$ & 5 & $\begin{array}{l}9 \\
2 \\
1 \\
1 \\
1 \\
1\end{array}$ & 1 & $\begin{array}{r}16 \\
2 \\
2 \\
1 \\
1 \\
1 \\
1 \\
1\end{array}$ \\
\hline 計 & 3 & 6 & 15 & 1 & 25 \\
\hline
\end{tabular}

\section{3. 検 討}

食道・気道異物症例の同期間内における総入 院患者数に対する割合は当科で $0.6 \%$, 県病院で
$2.2 \%$ あっあた。また来院ルートに関しては，当 科は全例紹介患者であり, 県病院は半数が直接 受診であった。したがって宮崎市周辺，宮崎県 中南部域において県病院は 2 次救急, 当大学は 
3 次救急病院的役割を果たしていると言える。

食道異物の種類では両病院とも貨幣, 魚骨が 多かった。年齢的には 6 歳未満が全体の $32 \%$ を 占め，70歳以上が $17 \%$ と多かった。年齢別に魚 骨と肉片を比較すると，両病院とも魚骨がより 高齢者に分布しており，肉片が高齢者に多いと いう報告1)と異なった。さらに県病院では鶏骨 より魚骨が高齢者に多かったことより, 症例数 は少ないが，高齢者ほど淡白な魚類を摂取する 機会が多いからではないかと解釈した。義歯異 物は高齢者ばかりでなく, 30歳代, 40歳代にも みられた。PTP 異物は当科ではみられなかった が，県病院では65例中 6 例あった。その殆んど は高齢者であり，大野2が指摘しているように 高齢者では顆粒状や液状の薬の方が服用しやす く, 剂型の改善が予防法につながるといえる。 乳幼児は貨幣が多いため診断がつきやすいが， 中には扔はじきやプラスチック玩具等のX線透 過性異物もあるので,十分な問診が必要となる。 食道異物の診断としては全例にX線撮影を行っ ているが, X線透過性異物は当科13例中 7 例 (54 $\%)$, 県病院65例中 40 例 $(62 \%)$, と総合して 6 割を占め，ときに診断に苦慮する場合がある。 魚骨異物疑いには xerography をルーチンにと つており，単純X線より異物像が明確であるた め, やや被曝量は多いが有効であることが多か つた。またPTP 異物の 1 例には, カプセル造影 法を用い，カプセルが停滞したことにより第 1 狭窄部の PTP 介在が強く示唆された（図 1 )。 この方法は簡便で安全性も高く, 補助診断の 1 つとして有用性が高いと思われる。ボタン異物 や魚骨異物について CT が有効であったとの報 告3)4)もあり，われわれは未経験であるが今後使 用の機会があれば試みたいと考えている。

摘出方法は両病院あわせて78例中63例が全麻 下であり，幼小児や高齢者が多いこと，非常に 安全に全麻がかけられるようになったこと, 尖 鋭異物の際にも体動なく粘膜への刺入の有無を 確認しやすいこと等から, 全麻下での摘出が増 えている。

摘出までの日数では，9割が 3 日目以内に摘 出しており,当科と県病院の間に差はなかった。 1 例40日間介在した肉片異物症例があったが, 本例は食道造影にて mass 所見 (図 2 ) があった

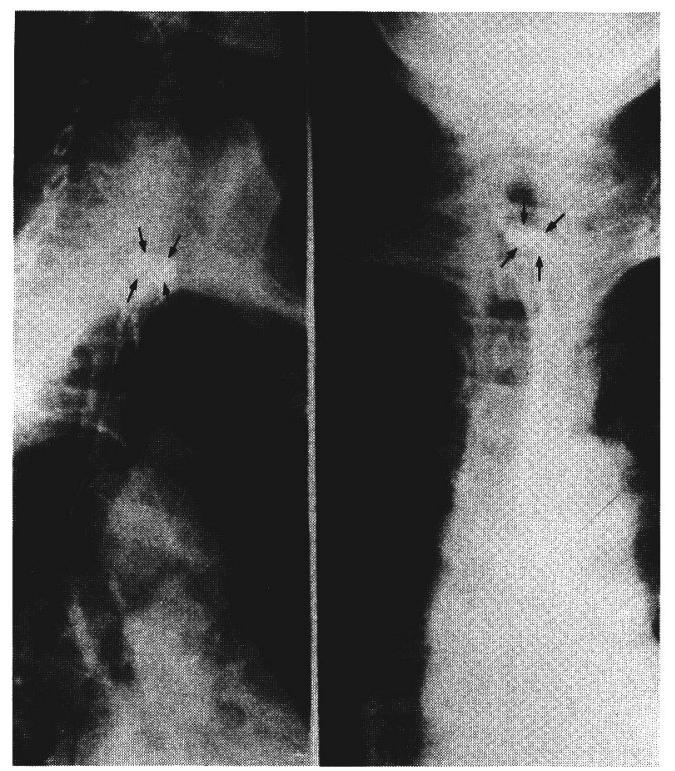

図 1 71歳女性。食道第 1 狭窄部の P T P 異物症例 のカプセル造影。

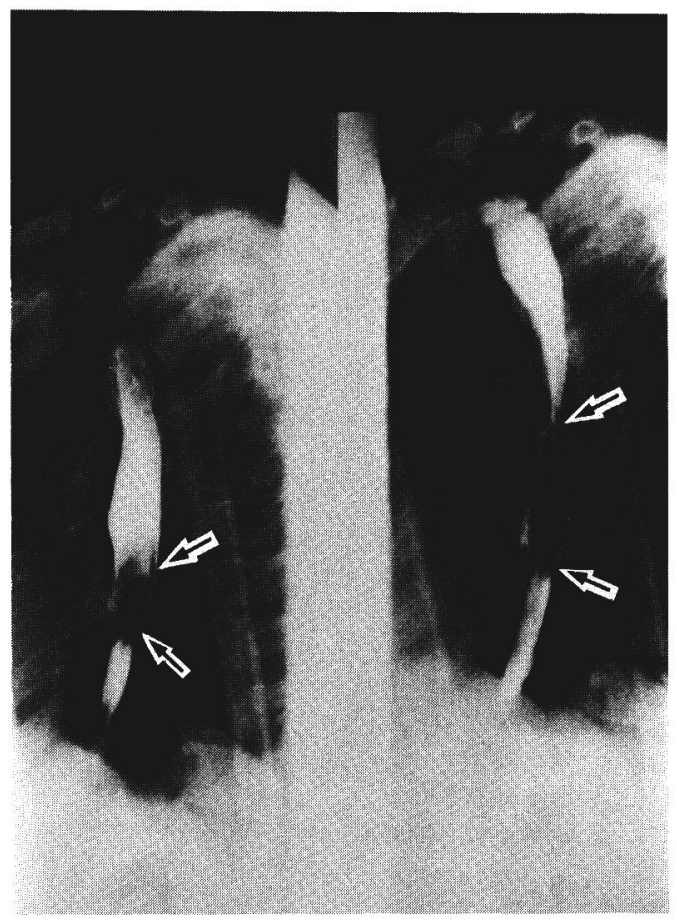

図２８歳男児。門歯より 18～23cmにわたり介在し 腫瘍性疾患と誤られていた肉片異物症例の食道 造影。 
表10 豆類気道異物症例の介在部位と年齢分布

\begin{tabular}{l|c|c|c|c|c|r|r}
\hline & $0 \sim 1$ & $1 \sim 2$ & $2 \sim 3$ & $3 \sim 4$ & $4 \sim 5$ & $5 \sim 6$ & 計 \\
\hline 気 管 & 1 & & & & & & 1 \\
右気管支 & 1 & 3 & & & 1 & & 5 \\
左気管支 & 1 & 6 & 1 & 2 & & 1 & 11 \\
両気管支 & & 1 & & & & & 1 \\
\hline 計 & 3 & 9 & 1 & 2 & 1 & 1 & 18 \\
\hline
\end{tabular}

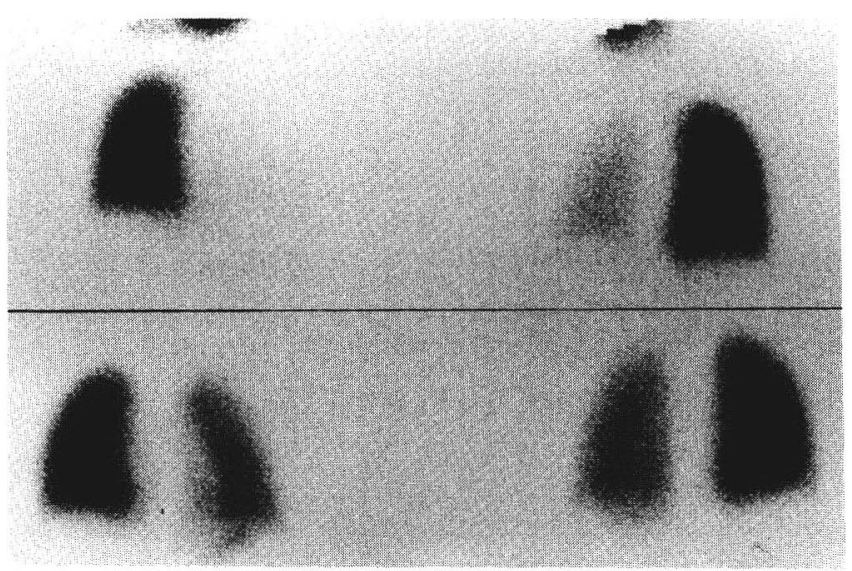

図 31 歳男児。左気管支鶏骨異物症例。 術前の肺換気 (上段), 血流(下段)シン チ。ともに左は前後像, 右は後前像。

図4 術後の肺換気 (上段), 血流 (下段) シンチ。ともに左肺野の改善を認める。
ために診断を誤り，耳鼻科受診が遅れた症例で あり，他科への啓蒙も大切であると思われた。

魚骨異物疑いで食道鏡検查を実施したが, 異 物は介在せず，粘膜損傷のみを認めた例が当科 6 例, 県病院 20 例あり, 食道周囲膿瘍を併発し 外切開を要した 1 例を除き, 全例鼻腔栄養と抗 生剂投与で軽快した。したがって臨床症状, 末 梢白血球等考慮し，X線学上異物介在の可能性 が低くとも時期を逸せず，食道鏡検査を実施す ることが望ましいし食道周囲膿瘍を事前に予防
することが大切である。

気道異物の種類では, ピーナッツが 25 例中 16 例，特に県病院では 20 例中 15 例と大半を占め, しかも 2 歳以下に集中しており，和田ら5)のア ンケート調査のごとく保護者の認識不足が最大 の原因であり，ピーナッツを与えない，子供の 近くで食べない等の注意を小児科医とともに喚 起していくべきであろう。

気道異物の介在部位は右気管支に多いという 諸家の報告5) 7) と異なる結果となった。しかし， 
小児のピーナッツ症例では左気管支が多いとい う報告8)9 があり，アーモンド 2 症例を加え，豆 類気道異物（表10）として年齢分布を検討して みたところ，年齢的片寄りはみられず，左気管 支が 6 割を占めた。右気管支は左気管支に比べ て太く短いために異物は入りやすいが，固定さ れなかった場合は左右を振子様に移動し，多少 上方にラッパ状に入口部が広がった形態をと る ${ }^{10)}$ 左気管支の方が入りにくいが出にくいこと になり，左に固定される可能性が高くなる。ま た左右の分岐角は 1 歳末満では左右差なく， 1 歳以上になると左分岐角が少しずつ大きくな る ${ }^{111}$ ため，乳幼児では成人より左気管支に異物 が入りやすいとの説明もあるが，われわれの例 では必ずしもそうではなかった。吸引時の体位 を含めた諸因子がからんでいることも考えられ る。今後単なる落下ではなく, 吸引力の左右差, それへの姿勢の影響等種々の見地からの研究が 待たれるところである。

気道異物の介在日数は食道異物のそれが両病 院で差がなかったのに対し，県病院と比較して 当科では長期にわたるものが多く, 両病院の性 格の差を示した。歯冠の 1 例を除く 4 例はすべ て当院小児科からの紹介で, 異物誤嶼の認識が なかったために, 呼吸器症状から小児科を受診 したものであった。県病院の小児の症例は殆ん どが 3 日目以内に摘出されているが，その年齢 は多くが 2 歳以下であるのに対し, 当科での小 児は 3 歳, 5 歳, 6 歳が 1 例ずつあり, 親の目 がそろそろ離れる年齢の小坚で，かえって異物 誤嚥の認識が遅れることが示唆された。

当科では，気道異物診断に際し緊急を要しな い例や，診断に苦慮する例では肺換気・血流シ ンチを施行して術前術後の呼吸状態を調べてお り，効果を上げている。図 3 , 図 4 に左気管支 䳕骨異物症例の肺換気・血流シンチを示す。

摘出については現在は殆んど ventilation bronchoscopeにて摘出しているが, 異物を摘 出した際，さらに末梢側にあるいは他枝に異物 が介在しないかを確認するために, flexible fiberscope を用いた例もあり，再確認には有用 であると思われる。摘出の際は大部分既製の鉤 や鉗子で摘出できたが，キルシュナー鋼線やラ ンボット鋼線を手術場で適当な型に曲げて銁を
作製し，異物を気管支鏡内へ引き入れるのに成 功した経験がある。術後合併症として抜管後陥 没呼吸が 30 分持続した例が 1 例あったが，他は 重篤な合併症もなく全例安全に摘出しえた。

\section{4. 結 語}

1. 過去 9 年間の当教室と県立宮崎病院の気 道・食道異物症例103例について臨床統計的観察 を試みた。

2. 食道異物计貨幣・魚骨・肉片の順に多く, 6 歳未満が 3 割を占めた。X線透過性異物が 6 割あった。

3. 気道異物ではピーナッツが 6 割強であっ た。10歳代〜60歳代は症例がなく，2 歳以下が 大半を占めた。気管支介在の左右比は予想に反 して $5: 2$ で左気管支に多い結果となった。

4. 来院ルートや介在日数等から県病院が 2 次救急，当科が 3 次救急病院的役割を果たして いると考えられた。両病院の差は気道異物症例 の異物介在日数に顕著に表われた。

5 . 異物診断に際し, 肺換気・血流シンチ等 種々の新しい検查法についても述べた。

本論文の要旨は第 1 回九州ブロック連合地方部会 学術講演会において発表した。

\section{文献}

1）鶴田至宏・他：当教室における異物症の変遷一 過去51年間の統計的観察一, 日耳鼻, $87: 1527-$ 1537, 1984.

2 ) 大野政一：PTP 包装誤嬩事故, 医学とあゆみ, $116: 572-573,1981$.

3）黄田川徹・他：CT が診断に有効であった小坚 食道異物の 1 例, 日気食会報, 32:311-315, 1981.

4 ) 兵行和: 気道 ・食道異物症の診断, 松永喬編, 気道・食道異物症臨床の実際, pp. 60-78, 篠原出 版, 東京出版, 1983.

5 ) 和田好弘・他：当教室 7 年間の食道及び気管・ 気管支異物の統計的観察, 日気食会報, 37：262267, 1986.

6 ）小宗静男・他：最近10年間のわが教室における 下気道異物の統計的観察と長期介在例についての 検討，耳鼻，22：599-607, 1976.

7）桑内隆郎・他：当教室開設時より 7 年間の食道 及び気管・気管支異物の統計的観察, 日気食会報, 32 : 339-344, 1981.

8 ）西条茂·他：気道異物症例の統計的観察, 耳鼻, 
$25: 319-322,1979$.

9 ) 大戸武久・他：当教室 10 年間の気道および食道 異物の臨床統計的観察, 日気食会報, 32:241-248, 1981.

10）東紘一郎・他：気管分岐部の形態一気管支異物 存在部位と関連して一, 日気食会報, $33: 245-249$, 1982.

11）金子省三・他：小児気管支異物の介在側につい
て, 日気食会報, 33:31-36, 1982.

(別刷請求： $=889-16$ 宮崎県宮崎郡清武町 宮崎医科大学耳鼻咽喉科学教室 狩野 季代

（投稿 1986 年12月 6 日） 